\title{
Dissolved ozone in biological fluid monitored by optical device operating in the red-infrared region
}

\author{
Henrique Cunha Carvalho*, Milene da Silva Melo, Carlos José de Lima, Renato Amaro Zângaro
}

\begin{abstract}
Introduction: When a gas is used for therapy, often the kinetic behavior and their distribution in biological systems is not known, leading to unsatisfactory results for clinical application. The use of ozone in living organisms has been scientifically released worldwide under the name of ozone therapy. The efficacy of this technique is determined primarily by the diffusion of gas within the tissues or fluids and which determines their action in the entire target region. We propose the development of technique to monitoring the $\mathrm{O}_{3}$ dissolved in the biological fluid using an optical device operating in the red-infrared region. Methods: The recombination of $\mathrm{O}_{3}$ in $\mathrm{O}_{2}$ enables the monitoring of the latter by the measurement of $\mathrm{SpO}_{2}$, and, based on this phenomenon, we propose to use an optical device operating in the red-infrared region to monitoring indirectly the diffusion of $\mathrm{O}_{3}$ in fluids. The system was based on optomechanical arrangement using a capsule containing fluid that was ozonated or oxygenated during the process. A pulse oximeter is a noninvasive device used for continuously measure of $\mathrm{SpO}_{2}$ resulting from the recombination of ozone. Results: The measurements of $\mathrm{SpO}_{2}$ when subjected to ozone and oxygen, showed an increased rate of $\mathrm{SpO}_{2}$ function of time for both cases reaching its peak in 80 s and 160 s, respectively. The experimental data concerning the $\mathrm{SpO}_{2}$ saturation as a function of time can be fitted by the theoretical model, showing a good correlation between them. Conclusion: A technique was developed using an optical device operating in the red-infrared region to monitoring ozone dissolved in biological fluid, showing a simple and effective way to indirectly monitoring the presence of ozone in fluids.
\end{abstract}

Keywords Ozone, Biological fluid, Diffusion, Recombination, Optical device, Red-infrared region.

\section{Introduction}

The use of ozone in living organisms has been widely publicized primarily on its action on bacteria, fungi, protozoa and viruses (Bocci et al., 2011a; Loeb, 2011). Numerous other biological and medical applications has been scientifically tried and reported around the world under the name of ozone therapy.

Ozone involved in redox balance, being a powerful oxidant that reacts immediately when in contact with biological fluids, inducing molecules directly on the balance of reactive oxygen species (ROS), which influence many biochemical events in the cell metabolism, providing antimicrobial effects benefits in addition to repair and balance of the target organism (Bocci et al., 2011a).

Thus, satisfactory results have been obtained in the treatment of diabetic foot (Wainstein et al., 2011), hepatitis (Zaky et al., 2011), cancer (Schulz et al., 2008), coronary heart disease (Martínez-Sánchez et al., 2012), atherosclerosis (Delgado-Roche et al., 2013), as a disinfecting agent in microorganisms causing nosocomial infections (Doan et al., 2012; Zoutman et al., 2011), and others.
When a gas is used for therapeutic purposes, often their kinetic behavior and their distribution in biological systems is not known, leading to unsatisfactory results when clinical application. The application of ozone therapy efficacy is determined primarily by the diffusion of gas within the tissues or fluids and which determines their action in the entire target region. The techniques commonly used to monitoring the diffusion of ozone fluids are invasive (Buchan et al., 2005; Loeb, 2011), which prevents monitoring systems such as sterile blood. Noninvasive optical techniques may be used in the UV region at $254 \mathrm{~nm}$ (Gao et al., 2012; Kalnajs and Avallone, 2010), but this spectral region cannot be applied in biological fluids due to high radiation absorption UV blood.

The recombination of $\mathrm{O}_{3}$ in $\mathrm{O}_{2}$, allows the monitoring of the latter by the measurement of $\mathrm{SpO}_{2}$ and based on this phenomenon, we propose a new approach to monitoring the $\mathrm{O}_{3}$ dissolved in the biological fluid using a simple and ingenious optomechanical device without the need to use $\mathrm{O}_{3}$ meter. 


\section{Methods}

The present study aims to determine the diffusion of ozone gas in fluids by measuring $\mathrm{SpO}_{2}$. The model was proposed in order to be able to perform real-time monitoring, noninvasively and nondestructively, using such a pulse oximeter operating in the region red - infrared. A system was developed based on the use of an optical oximeter (MD-300C - Moriya JG), which operates at two emission wavelengths, $\lambda_{1}$ and $\lambda_{2}$, the first of which presents high absorption by oxyhemoglobin and second low absorption. The $\mathrm{SpO}_{2}$ absorption corresponds to the difference between these two variables. As a biological fluid, was used $0.8 \mathrm{~mL}$ of whole bovine milk, type $\mathrm{C}$, with 10 samples, five submitted to the flow of oxygen and five others submitted to the flow of ozone. This fluid was used due to optical scattering characteristics, which facilitates the detection of the $\mathrm{SpO}_{2}$, and the model can be easily implemented in blood.

Pulse oximetry is based on light transmittance of hemoglobin. The light transmission coefficient of a substance is determined by the Beer-Lambert Law, which states that the concentration of an unknown solute in a solvent may be determined by absorption/scattering of light. In this case, solutes are oxyhemoglobin and reduced hemoglobin, and blood as the solvent.

During systole, the blood system is filled, increasing blood volume and absorption/scattering of light. During diastole, blood volume and light absorption/scattering reach their lowest point. The pulse oximeter operates synchronously with the cardiac pulse and $\mathrm{SpO}_{2}$ is obtained from the difference between the maximum and minimum absorption/scattering intensities during systole and diastole. In this case, two wavelengths are used, $\lambda_{1}(660 \mathrm{~nm})$ that is highly absorbed by oxyhemoglobin and $\lambda_{2}(910 \mathrm{~nm})$ which is absorbed by all the others components present in the tissue (Figure 1). The difference of intensity between the two signals expressed $\mathrm{SpO}_{2}$. In this work, the solvent is milk and solutes are ozone and oxygen.

The system of $\mathrm{SpO}_{2}$ was developed according to the diagram shown in Figure 2, using an optical oximeter having in its interior a capsule containing milk that received the gas flow. In this case, the finger is a capsule and the biological tissue is the milk inside of the capsule.

To observe the ability of diffusion in the milk a preliminary experiment used pure oxygen, and the results were used as reference of oxygen saturation. A second experiment was then conducted in order to determine the recombination of $\mathrm{O}_{3}$ in $\mathrm{O}_{2}$, and in this case, ozone was infused into the milk and $\mathrm{SpO}_{2}$ were monitored by the oximeter.

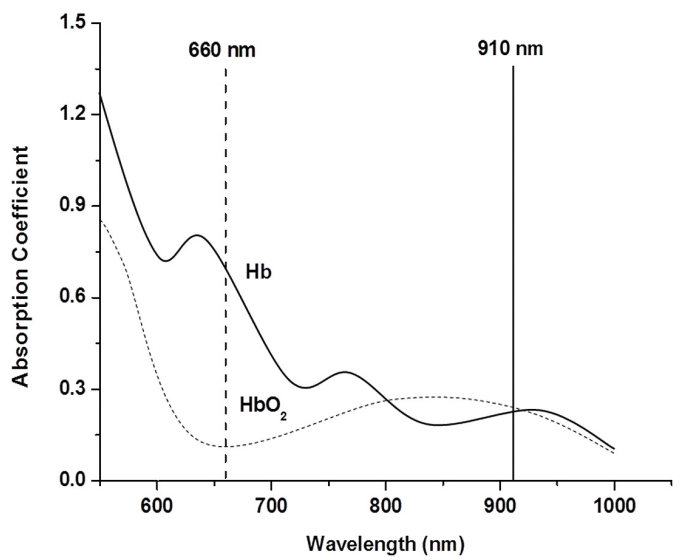

Figure 1. Operation principle of the pulse oximeter.

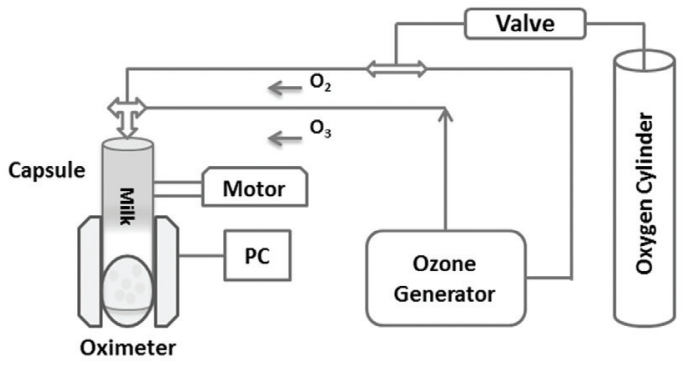

Figure 2. Set-up for measurement of $\mathrm{SpO}_{2}$ in biological fluids.

For their timing, the oximeter requires mimicking the human physiological system, which is based on the systole/diastole. In this case, this condition was obtained by moving the milk contained in the capsule. The movement is developed with the aid of an eccentric device, powered by a stepper motor operating at $60 \mathrm{rpm}$. The diffusion in the milk was provided by two gas lines, $\mathrm{O}_{2}$ and $\mathrm{O}_{3}$, both operating at a flow rate of $1 / 32 \mathrm{~L} / \mathrm{min}$, at different times, and the ozone generator used (OzonLife - Medical Systems) was able to provide $40 \mathrm{mg} / \mathrm{L}$.

Several models have been proposed to describe the transfer of ozone from the gas phase to the liquid phase (Bin, 2006). Generally, these models postulate that the concentration in both phases is homogeneous, except in the gas-liquid interface area. To determine the mass transfer coefficient $\left(\mathrm{K}_{\mathrm{La}}\right)$ is necessary to calculate the mass balance of the limiting phase (liquid), which is given by Equation 1 (Kunz et al., 1999):

$\mathrm{dC}_{\mathrm{L}} / \mathrm{dt}=\mathrm{K}_{\mathrm{La}} \times\left(\mathrm{C}_{\mathrm{L}}^{\text {sat }}-\mathrm{C}_{\mathrm{L}}\right)-\mathrm{K}_{\mathrm{d}} \times \mathrm{C}_{\mathrm{L}}$

where, $\mathrm{K}_{\mathrm{La}}$ : volumetric mass transfer coefficient $\left[\mathrm{min}^{-1}\right] ; \mathrm{C}_{\mathrm{L}}$ sat: saturation concentration of gas in solution [mg. $\left.\mathrm{L}^{-1}\right] ; \mathrm{C}_{\mathrm{L}}$ : concentration of ozone in solution 
[mg. $\left.\mathrm{L}^{-1}\right] ; \mathrm{K}_{\mathrm{d}}$ : kinetic constant of ozone decomposition $\left[\mathrm{min}^{-1}\right] ; \mathrm{C}_{\mathrm{L}}: \mathrm{t}$ : time of ozonation [min].

\section{Results}

The experiment was conducted to determine the $\mathrm{SpO}_{2}$ sample of $0.8 \mathrm{~mL}$ of milk, when this was ozonated or oxygenated. The results showed that in both cases, saturation occurs at relatively short times, of the order of a few minutes, which can be seen in Figures 3 and 4 .

Because the specifics of the experiment, the oximeter response starts from $75 \%$, and therefore the Figures 3 and 4, has its origins located in this region. The measurements of $\mathrm{SpO}_{2}$ when subjected to ozone and oxygen, showed an increased rate of $\mathrm{SpO}_{2}$ function of time for both cases reaching its peak in $80 \mathrm{~s}$ and $160 \mathrm{~s}$, respectively. The experimental data concerning the $\mathrm{SpO}_{2}$ saturation as a function of time can be fitted by the theoretical curves obtained from Equation 2, showing a good correlation between them.

$\mathrm{C}_{\mathrm{O} 3}=\mathrm{a}-\mathrm{b} \times \mathrm{e}^{(-\mathrm{t} / \mathrm{c})}$

where, $\mathrm{C}_{\mathrm{O} 3}$ : ozone concentration [mg. $\mathrm{L}^{-1}$ ]; $\mathrm{a}, \mathrm{b}$ and c: parameters; $\mathrm{t}$ : time [min].

\section{Discussion}

The ozone decomposes in water spontaneously through complex mechanisms involving free radical generation. Due to the high water concentration in the milk, can be considered in this case that the mechanism of decomposition of ozone in milk is similar to that of water.

During the recombination of $\mathrm{O}_{3}$ in $\mathrm{O}_{2}$, two reaction mechanisms are understood in the liquid, the direct oxidation of compounds by the ozone and indirect oxidation of compounds by hydroxyl free radicals produced during the decomposition of $\mathrm{O}_{3}$. In this case, the free radicals present, determine the rate of reaction, and also the regeneration of the superoxide radical $\mathrm{O}_{2}$-ion or proton form $\mathrm{HO}_{2}$, derived from the hydroxyl radical $(\mathrm{OH})$, which means the consumption of 1 mol of ozone (Guerrero, 2005). As a result, all species capable of consuming hydroxyl radicals without regenerating the superoxide ion will produce a stabilizing effect on the ozone molecule in the sample. This effect associated with those produced by-products, provides greater quantity of molecular oxygen, resulting in a smaller time interval for increased saturation $\mathrm{SpO}_{2}$.

The recombination of $\mathrm{O}_{3}$ in $\mathrm{O}_{2}$ depends mainly on the type of flow, gas solubility and temperature. The type of flow is defined by the Reynolds number (Re) according to Equation 3, and values of "Re" greater

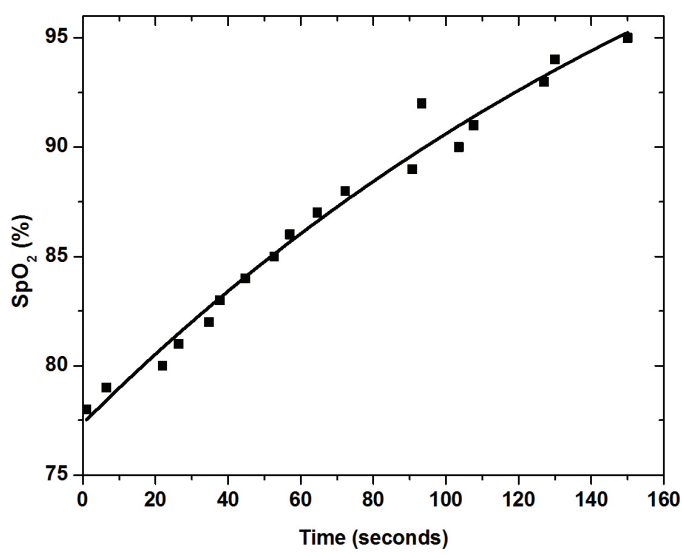

Figure 3. $\mathrm{SpO}_{2}$ of milk sample under oxygen action. Dots represent average experimental values; continuous line represents the trend line of the data obtained from Equation 1.

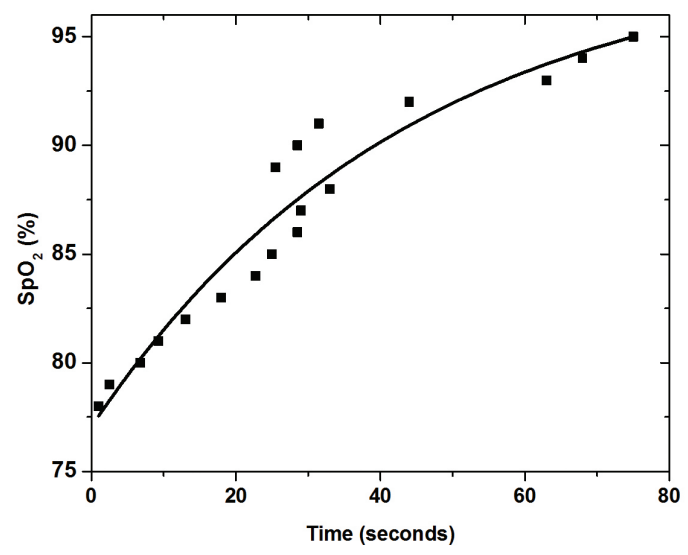

Figure 4. $\mathrm{SpO}_{2}$ of milk sample under ozone action. Dots represent average experimental values; continuous line represents the trend line of the data obtained from Equation 1.

than 2400, as set turbulent flow. This experiment was carried out under atmospheric pressure and the calculated Reynolds number was equal to 16405 , characterizing it as turbulent flow. In order to reduce the influence of temperature on the process, the experience was performed at a constant temperature equal to $21^{\circ} \mathrm{C}$.

$\operatorname{Re}=\mathrm{D} \times \mathrm{v} \times \rho / \mu$

Where, Re: Reynolds number [dimensionless]; D: diameter of capsule $=0.08[\mathrm{~m}]$; v: velocity of flow $=6.217\left[\mathrm{~m} . \mathrm{s}^{-1}\right] ; \rho$ : density of milk at $21^{\circ} \mathrm{C}=1029$ $\left[\mathrm{Kg} / \mathrm{m}^{3}\right]$ and $\mu$ : viscosity of milk at $21{ }^{\circ} \mathrm{C}=2.1[\mathrm{cP}]$.

The concentration of ozone versus time expressed by Equation 2 is dependent on the solubility of the gas, which in turn directly affects the mass transfer. The data concerning the solubility of gases in liquids 
have great theoretical and practical interest, where the processes involved in solubility/mass transfer between gas and liquid are crucial to monitoring the diffusion of gas in the interface processes.

As shown in Figures 3 and 4, to reach the oxygen saturation $\left(\mathrm{SpO}_{2}\right)$ at $95 \%$ produced by ozonized fluid requires half time if compared when the fluid is oxygenated, which is supported by the calculations obtained from Equation 2. This analysis sparked numerous questions about which mechanisms are involved in this phenomenon. Analyzing the variables involved in the process, different studies have reported a significant difference in solubility of ozone and oxygen (Bin, 2006; Bocci et al., 2011a) when dissolved in water at normal temperature and pressure, and this difference according to our analysis the most plausible answer to explain this result. Bin (2006) also presented several relationships between different expressions of the solubility of ozone in liquids. Several authors have also published data on solubility of ozone in water (Rischbieter et al., 2000; Kuosa et al., 2004; Levanov et al., 2008), indicating that it is about ten times more soluble than molecular oxygen (Bocci et al., 2011b), supporting this hypothesis. Another aspect to be considered when the milk is ozonized, that is, the ozone decomposition constant $\left(\mathrm{K}_{\mathrm{d}}\right)$ increases exponentially as a function of the presence in milk of different molecules, increasing the rate of recombination $\mathrm{O}_{3}$, with consequent reduction in the time to reach saturation. The relative high $\mathrm{pH}$ of the sample, in this case close to 7.0, also contributes to this phenomenon. In this situation the value of $\mathrm{K}_{\mathrm{d}} \mathrm{can}$ be as high enough to compete with the value of $\mathrm{K}_{\mathrm{La}}$, making the recombination- $\mathrm{O}_{3} \mathrm{O}_{2}$ occurs immediately after diffusion of ozone in liquid medium, explaining why the $\mathrm{SpO}_{2}$ induced by the action of ozone is faster than that induced by oxygen.

The results allow us to conclude that the technique, developed using an optical device operating in the red-infrared region to monitoring ozone dissolved in biological fluid, provides a simple and effective way to indirectly monitor the presence of ozone in fluids.

\section{Acknowledgments}

CAPES (Coordination for the Improvement of Higher Education Personnel) and FAPESP (São Paulo Research Foundation) for the financial support.

\section{References}

Bin AK. Ozone solubility in liquids. Ozone: Science \& Engineering. 2006; 28(2):67-75. http://dx.doi. org/10.1080/01919510600558635
Bocci V, Zanardi I, Travagli V. Oxygen/ozone as a medical gas mixture. A critical evaluation of the variuos methods clarifies positive and negative aspects. Medical Gas Research. 2011a; 1(1):1-6. PMid:22146387 PMCid:PMC3231820. http://dx.doi.org/10.1186/20459912-1-6

Bocci V, Zanardi I, Travagli V. Ozone acting on human blood yields a hormetic dose-response relationship. Journal of Translational Medicine. 2011b; 9(66):1-11.

Buchan KAH, Martin-Robichaud DJ, Benfey TJ. Measurement of dissolved ozone in sea water: a comparison of methods. Aquacultural Engineering. 2005; 33(3):225-31. http://dx.doi.org/10.1016/j.aquaeng.2005.02.002

Delgado-Roche L, Martínez-Sánchez G, Re L. Ozone oxidative preconditioning prevents atherosclerosis development in New Zealand white rabbits. Journal of Cardiovascular Pharmacology. 2013; 61(2):160-5. PMid:23222311. http:// dx.doi.org/10.1097/FJC.0b013e31827a820d

Doan L, Forrest H, Fakis A, Craig J, Claxton L, Khare M. Clinical and cost effectiveness of eight disinfection methods for terminal disinfection of hospital isolation rooms contaminated with Clostridium difficile 027. Journal of Hospital Infection. 2012; 82(2):114-21. PMid:22902081. http://dx.doi.org/10.1016/j.jhin.2012.06.014

Gao RS, Ballard J, Watts LA, Thornberry TD, Ciciora SJ, McLaughlin RJ, Fahey DW. A compact, fast UV photometer for measurement of ozone from research aircraft. Atmospheric Measurement Technology. 2012; 5:2201-10. http://dx.doi. org/10.5194/amt-5-2201-2012

Guerrero PJ. Air quality modeling in very complex terrains: ozone dynamics in the northeastern Iberian peninsula [thesis]. Barcelona: Universidade Politécnica da Catalunha, 2005.

Kalnajs LE, Avallone LM. A novel lightweight low-power dual-beam ozone photometer utilizing solid-state optoelectronics. Journal of Atmospheric Oceanic Technology. 2010; 5(5):869-80. http://dx.doi. org/10.1175/2009JTECHA1362.1

Kunz A, Freire RS, Rohwedder JJR, Duran N, Mansilla H, Rodriguez J. Construção e otimização de um sistema para produção e aplicação de ozônio em escala de laboratório. Química Nova. 1999; 22(3):425-28. http://dx.doi.org/10.1590/ S0100-40421999000300022

Kuosa M, Laari MA, Kallas J. Determination of the Henry's coefficient and mass transfer for ozone in a bubble column at different $\mathrm{pH}$ values of water. Ozone: Science \& Engineering. 2004; 26(3):277-86. http://dx.doi. org/10.1080/01919510490455746

Levanov AV, Kuskov IV, Antipenko EE, Lunin VV. The solubility of ozone in aqueous solutions of sulfuric, phosphoric, and perchloric acids. Russian Journal of Physics Chemical A. 2008; 82(7):1126-31. http://dx.doi. org/10.1134/S0036024408070133

Loeb BL. Ozone: Science \& Engineering: Thirty-three years and growing. Ozone: Science \& Engineering. 2011; 33(4):32942. http://dx.doi.org/10.1080/01919512.2011.584302

Martínez-Sánchez G, Delgado-Roche L, Diaz-Batista A, Péres-Davidson G, Re L. Effects of ozone therapy on 
haemostatic and oxidative stress index in coronary artery disease. European Journal of Pharmacology. 2012; 691(13):156-62. PMid:22796450. http://dx.doi.org/10.1016/j. ejphar.2012.07.010

Rischbieter E, Stein H, Schumpe A. Ozone solubilities in water and aqueous salt solutions. Journal of Chemical Engineering Data. 2000; 45(2):338-40. http://dx.doi. org/10.1021/je990263c

Schulz S, Häussler U, Mandic R, Heverhagen JT, Neubauer A, Dünne AA, Werner JA, Weihe E, Bette M. Treatment with ozone/oxygen-pneumoperitoneum results in complete remission of rabbit squamous cell carcinomas. International Journal of Cancer. 2008; 22(10):2360-7. PMid:18224691. http://dx.doi.org/10.1002/ijc.23382
Wainstein J, Feldbrin Z, Boaz N, Harman-Boehm I. Efficacy of ozone-oxygen therapy for the treatment of diabetic foot ulcers. Diabetes Technology Therapy. 2011; 13(12):1255-60. PMid:21751891. http://dx.doi.org/10.1089/dia.2011.0018

Zaky S, Kamel SE, Hassan MS, Sallam NA, Shahata MA, Helal SR, Mahmoud H. Preliminary results of ozonetherapy as a possible treatment for patients with chronic hepatitis C. Journal of Alternative and Complement Medicine. 2011; 17(3):256-63. PMid:21417811. http:// dx.doi.org/10.1089/acm.2010.0016

Zoutman D, Shannon M, Mandel A. Effectiveness of a novel ozone-based system for the rapid high-level disinfection of health care spaces and surfaces. American Journal of Infection Control. 2011; 39(10):873-9. PMid:21546123. http://dx.doi.org/10.1016/j.ajic.2011.01.012

\footnotetext{
Authors

Henrique Cunha Carvalho*, Milene da Silva Melo, Carlos José de Lima, Renato Amaro Zângaro Instituto de Engenharia Biomédica, Universidade Camilo Castelo Branco - UNICASTELO, Parque Tecnológico de São José dos Campos, Estrada Doutor Altino Bondesan, 500, Eugênio de Melo, CEP 12247-016, São José dos Campos, SP, Brasil
}

Carlos José de Lima, Renato Amaro Zângaro

Associação Cidade da Ciência Tecnologia e Educação - CITÉ, São José dos Campos, SP, Brasil. 